\title{
The Essence of Intellectual Property Rights Under Article 17(2) of the EU Charter
}

\author{
Martin Husovec ${ }^{*}$
}

(Received 01 May 2019; accepted 30 May 2019)

\begin{abstract}
Smoking kills. It is also very costly, which is why many governments try to change the habits of their citizens, including by changing the packaging of the products they buy. Of course, tobacco firms are pushing against such laws. They see their rights, in particular, rights to intellectual property, violated. They argue that such legislative changes take away the essence of their hard-earned IP rights and should not be permissible. They point out that the CJEU is allegedly redefining the "essence" of fundamental rights and its function in the system of limitations and developing a set of core inviolable rights.

How justified are these arguments? The absolute theory of essence says that the essence of rights cannot be interfered with or taken away, including by the legislator. The relative theory of essence, on the other hand, claims that interference with essence is just a more serious interference which is still subject to the typical proportionality analysis. Therefore, the adoption of either of these two theories has profound consequences. What might constitute the essence of intellectual property rights? When are legislators touching upon it? Is the CJEU really advancing a notion of essence that can prevent legislative changes, or at least make them very difficult? The answer to all these questions depends on our understanding of what constitutes the "essence" of intellectual property rights, and what consequences this notion has under Article 17(2) of the EU Charter of Fundamental Rights.
\end{abstract}

Keywords: Intellectual property; essence; human rights; Article 17(2); EU Charter

\section{A. Introduction}

Smoking kills. It is also very costly, which is why many governments try to change habits of their citizens through various strategies, including by changing the packaging of the products they buy. Of course, tobacco firms are pushing against such laws. They see their rights-in particular those related to intellectual property - as violated. They argue that such legislative changes take away the essence of their hard-earned IP rights and should not be permissible. They point out that the Court of Justice of the European Union (hereinafter "CJEU") is allegedly redefining the "essence" of fundamental rights and its function in the system of limitations and developing a set of core inviolable rights.

How justified are these arguments? One the one hand, the absolute theory of essence says that the essence of rights cannot be interfered with or taken away, including by the legislator. The relative theory of essence, on the other hand, claims that an interference with the essence is just

${ }^{\star}$ Martin Husovec is Assistant Professor at Tilburg University—appointed jointly by Tilburg Institute for Law, Technology and Society \& Tilburg Law and Economics Center-and Affiliate Scholar at Stanford Law School's Center for Internet \& Society (CIS). I would like to thank Christophe Geiger, Jonathan Griffiths, Bernt Hugenholtz, Daniël Jongsma, Orla Lynskey, Alexander Peukert, and Caterina Sganga for their debates and comments related to this work. I would also like to thank to Pedro Reisinho for his excellent research assistance. 
a more serious interference that is still subject to the typical proportionality analysis. Therefore, adoption of either of these two theories has profound consequences. What might constitute the essence of intellectual property rights? When are legislators touching upon it? Is the CJEU really advancing a notion of essence that can prevent legislative changes, or at least make them very difficult? The answer to all these questions depends on our understanding of what constitutes the "essence" of intellectual property rights, and what consequences this notion has under Article 17(2) of the EU Charter of Fundamental Rights.

This Article proceeds as follows: First, it explains how intellectual property rights are protected in the EU Charter. Second, it puts this protection in the context of the absolute and relative theories of the role of the essence of rights. Third, it explores the case-law of the CJEU-and partly the European Court of Human Rights (hereinafter "ECtHR") — to determine to which theory the CJEU subscribes. Fourth, and lastly, after concluding that the CJEU does not yet advance an absolute theory of the essence of rights in intellectual property law, it briefly explores sources of constitutional traditions on which the CJEU might draw should it decide to do so in the future.

This Article concludes that the notion of "essence" is hardly applied in the context of intellectual property rights. Any reference to essence in the case-law of the CJEU points only towards a higher level of scrutiny, but not towards an untouchable core of rights. The essence is only viewed as a tool to identify the core features of the legislative design of various intellectual property rightstheir substance-which are then weighed against conflicting interests. Nevertheless, the essence of legislative design is not the same as the essence of a fundamental right.

A brief analysis of the constitutional traditions of England, Germany, and Slovakia shows that different models co-exist on the national level. On the one hand, German and Slovak constitutional jurisprudence do recognize inviolable core rights, although the obligations differ slightly. The UK jurisprudence, on the other hand, equates its mechanisms with the Convention and the EU Charter, which, according to its domestic court's reading, provides no inviolable core rights at this point.

Next to national constitutions, an important source of constitutional traditions is also the International Covenant on Economic, Social and Cultural Rights ("ICESCR"), which includes an obligation to provide for a right of creators to benefit from their works. ${ }^{1}$ Although these "creator's rights" protect a wider range of interests-including non-economic ones in particular-they provide for a useful external source of inspiration for conceptualizing what ought to constitute the essence.

\section{B. Article 17(2) and Article 1 of Protocol 1 of the European Convention of Human Rights}

Intellectual property rights are legal constructs which govern the use of information. They mostly come in the form of exclusive rights which are expected to be traded on the market in exchange for licensing revenue. Exclusivity and remuneration are thus two defining features of IP rights. At the moment, we have more than a dozen different intellectual property rights. ${ }^{2}$ The most prominent categories of rights include copyright, patent, and trademark rights. With technological progress, IP rights continue growing in number as lobbying efforts by societal groups encourage legislators to create new forms of protections. The latest copyright reform in the EU, for instance, legislates for a new right for press publishers. ${ }^{3}$ At the same time, legislators almost never revisit obsolete IP

\footnotetext{
${ }^{1}$ International Covenant on Economic, Social and Cultural Rights art. 15(1)(c), Jan. 3, 1976, 993 U.N.T.S. 3 [hereinafter ICESCR].

${ }^{2}$ These include: Copyrights, performer's rights, phonogram producer's rights, broadcaster's rights, sui generis database rights, patents, utility models, registered and non-registered designs, trademarks, geographical indications, plant varieties, and semiconductors.

${ }^{3}$ See Commission Proposal for a Directive of the European Parliament and of the Council on Copyright in the Digital Single Market, art. 11, COM (2016) 593 final (Sept. 14, 2016).
} 
regimes, which results in a constant stacking and expansion of intellectual property rights in the legal system.

\section{Why Do Intellectual Property Rights Exist?}

Why do all IP rights exist? As simple as this question seems, it is actually very difficult to answer. Centuries of law-making have created a very fragmented landscape that cannot be explained with a single reason. There are many functions of IP rights within society, each specifically tailored to a particular IP regime. For instance, while both copyright and patent rights are often characterized as economic incentives for future creativity and innovation, copyright law includes a stronger moral component. Trademarks, rather, serve the purpose of market transparency and reducing the consumer's search costs.

Therefore, the term "intellectual property" is an elusive category which harbors many different instruments with entirely different goals. What they have in common is that they are all, by and large, economic instruments of innovation policy. Nevertheless, some more than others also have strong dignitary goals, which might be protected by non-economic fundamental rights of the EU Charter-for example, Articles 1, 3(1), and 7. Identifying the rationale behind these rights is important in order to understand what values they embody and thus the reasons for which the legislator attributes importance to them.

According to the CJEU, IP rights are created for the purpose of fulfilling certain social goals. ${ }^{4}$ These are often articulated in the recitals of secondary EU law. ${ }^{5}$ Nevertheless, the "requirements of general interest which motivated the grant of the right" 6 differ for various IP rights. Although some prominent commentators question repeated references to "social function" as outdated ${ }^{7}$ with regard to intellectual property rights, the idea that these rights are only means to an end is in fact less controversial that it might seem for other rights. ${ }^{8}$ In fact, some national constitutional texts and jurisprudence articulate this instrumentalist view of IP rights very firmly. ${ }^{9}$ Most famously, the United States Constitution grants the US Congress powers to enact IP laws only " $[\mathrm{t}] \mathrm{o}$ promote the progress of science and useful arts."

When we look at the case-law of the CJEU, we can identify the following justifications for some of the most important intellectual property rights:

\footnotetext{
${ }^{4}$ See also ECJ, Case C-277/10, Martin Luksan v. Petrus van der Let, ECLI:EU:C:2012:65, Judgment of Feb. 9, 2012, para. 68. This is often discussed as a "social function of property." See Christophe Geiger, The Social Function of Intellectual Property Rights, or How Ethics Can Influence the Shape and Use of IP Law, in METHODS AND PERSPECTIVES IN INTELLECTUAL ProperTy 153-76 (Graeme B. Dinwoodie ed., 2014); Christophe Geiger, Implementing Intellectual Property Provisions in Human Rights Instruments: Towards a New Social Contract for the Protection of Intangibles, in RESEARCH HANDBOOK ON HUMAN RigHTS and Intellectual Property 661; Alexander Peukert, Intellectual Property as an End in Itself? 33 Eur. Intell. Prop. Rev. 67 (2011); Felix Leinemann, Die Sozialbindung des Geistigen Eigentums [The Social Binding of the Spiritual Property] (1998); Eric Pahud, Die Sozialbindung des Urheberrechts [The Social Binding of Copyright] (Berne Verlag ed., 2000); Caterina Sganga, Proprietizing European Copyright (2017).

${ }^{5}$ See Directive 2004/48/EC, of the European Parliament and of the Council of 29 April 2004 on the Enforcement of Intellectual Property Rights, 2004 O.J. (L 157) 46, 46 ("The protection of intellectual property is important not only for promoting innovation and creativity, but also for developing employment and improving competitiveness."). These goals are by no means exhaustive.

${ }^{6}$ Opinion of Advocate General Tesauro at para. 33, Case C-200/96, Metronome Musik v. Music Point Hokamp (Jan. 22, 1998), http://curia.europa.eu/juris/liste.jsf?language=en\&num=C-200/96.

${ }^{7}$ Steve Peers \& Sascha Prechal, Article 52 Scope and Interpretation of Rights and Principles, in THE EU CHARTER OF Fundamental Rights: A Commentary 1455, 1479 (Jeff Kenner et al. eds., 2014).

${ }^{8}$ See, infra, Section C.

${ }^{9}$ See Peukert, supra note 4.

${ }^{10}$ U.S. CONST. art. I, $\$ 8$, cl. 8.
} 
- For phonogram producers, in Metronome Musik the CJEU saw the rights "justified by the protection of the extremely high and risky investments which are required for the production of phonograms and are essential if authors are to go on creating new works." 11

- For author's and performer's rights, in Phil Collins the CJEU emphasized "the protection of the moral and economic rights" as the reason for their existence. ${ }^{12}$ Advocate General Szpunar in Funke Medien recently explained this in more detail:

Copyright has two main objectives. The first is to protect the personal relationship between the author and his work as his intellectual creation and therefore, in a sense, an emanation of his personality. This primarily involves the area of moral rights. The second objective is to enable authors to exploit their works economically and thus earn an income from their creative endeavours. ${ }^{13}$

The substance of copyright, in his view, is "respect for the relationship linking them to their works and the possibility of exploiting those works economically." ${ }^{4}$ In Pelham, he added that "[t] he main objective of copyright and related rights is to promote the development of the arts by ensuring artists receive revenue from their works, so that they are not dependent on patrons and are free to pursue their creative activity." 15

- For trademarks, in Hoffmann-La Roche the CJEU explained that their essential function "is to guarantee the identity of the origin of the trade-marked product to the consumer or ultimate user, by enabling him without any possibility of confusion to distinguish that product from products which have another origin."16

- For patents, in Huawei Advocate General Wathelet emphasized that:

[t]he essential objective of a patent is to ensure, in order to reward the creative effort of the inventor, that the owner of the patent has the exclusive right to use an invention with a view to manufacturing industrial products and selling them, either directly, or by granting licences to third parties, as well as the right to oppose infringements. ${ }^{17}$

This brief survey of case-law shows that the economic function of intellectual property is key in explaining why it exists. Nevertheless, some rights, such as copyright, are equally strongly underscored for their dignitary function - in particular the link to one's personality. This is important for the construction of essence within Article 17(2), which is of purely economic character. Noneconomic aspects of IP rights might find their protection under other fundamental rights enshrined in the EU Charter, such as the right to human dignity-Article 1-the right to integrity of a person-Article 3-and the right to respect of private life-Article 7.

\footnotetext{
${ }^{11}$ ECJ, Case C-200/96, Metronome Musik v. Music Point Hokamp, EU:C:1998:172, Judgment of Apr. 28, 1998, para. 24.

${ }^{12}$ ECJ, Case C-92/92, Collins \& Patricia Im-und Export v. Imtrat \& EMI Electrola, ECLI:EU:C:1993:847, Judgment of Oct. 20, 1993, para. 20.

${ }^{13}$ Opinion of Advocate General Szpunar at para. 58, Case C-469/17, Funke Medien NRW (Oct. 25, 2018), http://curia. europa.eu/juris/liste.jsf?language $=$ en $\&$ num $=\mathrm{C}-469 / 17$.

${ }^{14} I d$. at para. 38 .

${ }^{15}$ Opinion of Advocate General Szpunar at para. 83, Case C-476/17, Pelham (Dec. 12, 2018), http://curia.europa.eu/juris/ liste.jsf?num $=\mathrm{C}-476 / 17$.

${ }^{16}$ ECJ, Case C-102/77, Hoffman-La Roche v. Centrafarm, ECLI:EU:C:1978:108, Judgment of May 23, 1978, para. 7.

${ }^{17}$ Advocate General Opinion Wathelet at fn. 34, Case C-170/13, Huawei Technologies (Nov. 20, 2014), http://curia.europa. eu/juris/liste.jsf?num=C-170/13 (citing ECJ, Case C-15/74 Centrafarm BV v. Sterling Drug, ECLI:EU:C:1974:114, Judgment of Oct. 31, 1974, para. 9; ECJ, Case C-403/08, Football Association Premier League, Judgment of Oct. 4, 2011 , para. 107).
} 


\section{Supranational Sources of Protection}

On the global level, international human rights law does not speak of intellectual property rights. Article 27 of The Universal Declaration of Human Rights and Article 15 of the International Covenant on Economic, Social and Cultural Rights ("ICESCR") include an obligation for states to give everyone a right to the protection of the moral and material interests resulting from any scientific, literary, or artistic production of which he or she is the author. These so-called creator's rights are interlinked but should not be equated with intellectual property rights. Although the goals of the two systems might be often in sync, this is not necessarily always the case. Creators' rights deal only with a subset of interests protected under typical intellectual property laws. While patents and copyrights are more closely linked with authors' interests in their own scientific, literary, or artistic production, this link is virtually non-existent for other types of IP rights - for example, trademarks or sui generis database rights - or at least much weaker due to an emphasis on investment-for example, rights of phonogram producers and broadcasters. The most encompassing protection system within human rights law is therefore, unsurprisingly, one of property protection.

Historically, the first individually enforceable supra-national protection of intellectual property rights in Europe was developed under the auspices of the European Convention of Human Rights ("the Convention"). Its Article 1 of Protocol 1 (“A1P1"), which entered into effect in 1954, became a backbone of European human rights protection of intellectual property rights. The provision prescribes protection for the peaceful enjoyment of possessions. It circumscribes the types of interferences that are permissible in the Member States of the Council of Europe. These interferences usually take the form of direct actions of public authorities, including courts, but they may also arise from legislation. ${ }^{18}$

Since 1990, the case-law has accepted that various intellectual property rights qualify as "possessions." According to the ECtHR, this includes copyrights, ${ }^{19}$ patents, ${ }^{20}$ and trademarks,${ }^{21}$ including mere applications for them. ${ }^{22}$ The crucial requirement is that national law recognizes these rights, as the Convention itself has no pre-conceived notions of what shall constitute "possessions." Where national law — as interpreted by national courts—-foresees no IP rights, the ECtHR does not intervene, even though such situation could be otherwise questionable from the international public law perspective. ${ }^{23}$ Such complaints are then found to be outside ratione

\footnotetext{
${ }^{18}$ Marckx v. Belgium, App. No. 6833/74, para. 27 (June 13, 1979), http://hudoc.echr.coe.int/eng?i=001-57534 (“Article 25 of the Convention entitles individuals to contend that a law violates their rights by itself, in the absence of an individual measure of implementation, if they run the risk of being directly affected by it.").

${ }^{19}$ A.D. v. Netherlands, App. No. 21962/93, para. 3 (Jan. 11, 1994) (Eur. Comm'n on H.R.); Aral v. Turkey, App. No. 24563/ 94, para. 4 (Jan. 14, 1998) (Eur. Comm'n on H.R.); Dima v. Romania, App. No. 58472/00 (May 26, 2005), http://hudoc.echr. coe.int/eng?i=001-78043; Melnychuk v. Ukraine, App. No. 28743/03, para. 3 (July 5, 2005); Bălan v. Moldova, App. No. 19247/03, para. 34 (Jan. 29, 2008), http://hudoc.echr.coe.int/eng?i=001-84720; SC Editura Orizonturi SRL v. Romania, App. No. 15872/03, para. 70 (May 13, 2008), http://hudoc.echr.coe.int/eng?i=001-89794; SIA AKKA/LAA v. Latvia, App. No. 562/05, para. 41 (July 12, 2016), http://hudoc.echr.coe.int/eng?i=001-164659.

${ }^{20}$ Kline v. Netherlands, App. No. $12633 / 87$ (Oct. 4, 1990) (Eur. Comm'n on H.R.); Lenzing AG v. United Kingdom App. No. $38817 / 97$ (Sept. 9, 1998) (Eur. Comm'n on H.R.).

${ }^{21}$ Anheuser-Busch Inc. v. Portugal, App. No. 73049/01, para. 72 (Jan. 11, 2007), http://hudoc.echr.coe.int/eng?i=00178981; Paeffgen Gmbh v. Germany, App. Nos. 25379/04, 21688/05, 21722/05, 21770/05 (Sept. 18, 2007).

${ }^{22}$ See Laurence R. Helfer, The New Innovation Frontier? Intellectual Property and the European Court of Human Rights 49 HARV. INT'L L.J. 1 (2008); Sascha Sebastian, Geistiges Eigentum als europäisches Menschenrecht: Zur Bedeutung von Art. 1 des 1. Zusatzprotokolls zur EMRK für das Immaterialgüterrecht [Intellectual Property as a European Human Right-The Meaning of Article 1 of the 1st Additional Protocol to the ECHR for Intellectual Property Law], 62 GEWERBLICHER RECHTSSCHUTZ UND UrheberReCht INT'L 524 (2013); Christophe Geiger \& Elena Izyumenko, Intellectual Property Before the European Court of Human Rights, in Intellectual Property and the Judiciary 9 (Christophe Geiger et al. eds, 2018).

${ }^{23}$ Geiger \& Izyumenko, supra note 22, at 21-22 fn. 9; Henning Grosse Ruse-Khan, The Protection of InTELLECTUAL Property in International Law 230, 240 (2016); Alexander Peukert, The Fundamental Right to (Intellectual) Property and the Discretion of the Legislature, in Research HandBook on Human Rights ANd InTellectual Property, supra note 4 , at 132,138 .
} 
materiae of A1P1. ${ }^{24}$ As explained by Harris and others, A1P1 "is not a right to be put into the possession of things one does not already have, however strong the individual's interest in this happening may be." ${ }^{25}$ In other words, A1P1 essentially forces the governments to stick to its promises, or justify when they deviate from them, but never to proactively give new ones. ${ }^{26}$

When the state has already promised to grant IP rights, such rights can only be interfered with subject to the safeguards of A1P1. These safeguards differ depending on whether the interference qualifies as a control of use or deprivation. While control of use is an interference that requires proportionate state actions, deprivation - whether de iure or de facto-largely also dictates compensation. These requirements represent a basic articulation of the rule of law, which allows legislators to experiment but also holds them accountable if they completely disregard their own previous promises. Only once the possession is established in national law will the state possibly come under a positive obligation under A1P1, requiring it to take the measures necessary to protect property rights, including in relationships between individuals. ${ }^{27}$

\section{The EU Charter}

In the European Union, the constitutional protection of IP rights obtained a new impulse after the Lisbon Treaty entered into the force in 2009. Within the European Union's Charter of the Fundamental Rights ("the Charter"), Article 17(2) singled out intellectual property rights as explicitly protected subject matter, without clarifying the terms used or scope of protection offered. According to the official explanatory note, intellectual property was explicitly mentioned because of "its growing importance and Community secondary legislation." ${ }^{28}$ The explanatory note also confirms that the protection offered by Article 17(2) was modeled on A1P1. ${ }^{29}$ The vagueness of this provision prompted a considerable amount of scholarship trying to identify the contours of the protection under Article 17(2), its functions, and its future roles. ${ }^{30}$ Despite different views on the matter, the agreement seems to be that Article 17(2) does not come with any program of IP rights of its own, and leaves their design largely or entirely to the legislator. ${ }^{31}$

In just a few years, the Court of Justice of the European Union has used Article 17(2) to moderate disputes between various fundamental rights, to interpret provisions of secondary EU law, or

\footnotetext{
${ }^{24}$ See infra Section C(I).

${ }^{25}$ David Harris et al., Law of the European Convention on Human Rights 660 (2nd ed. 2009).

${ }^{26}$ Martin Husovec, Intellectual Property Rights and Integration by Conflict: The Past, Present and Future, 18 CAMBRIDGE Y.B. EUR. LEGAL STUD. 239 (2016).

${ }^{27}$ Zolotas v. Greece (No. 2), App. No. 66610/09, para. 39 (Apr. 4, 2013), http://hudoc.echr.coe.int/eng?i=001-116441 (summarizing the case-law); Broniowski v. Poland, App. No. 31443/96, para. 143 (Sept. 28, 2005), http://hudoc.echr.coe.int/eng? $\mathrm{i}=001-70326$.

${ }^{28}$ Explanations Relating to the Charter of Fundamental Rights, 2007 O.J. (C 303) 17, 23.

The wording has been updated but, in accordance with Article 52(3), the meaning and scope of the right are the same as those of the right guaranteed by the ECHR and the limitations may not exceed those provided for there. Protection of intellectual property, one aspect of the right of property, is explicitly mentioned in paragraph 2 because of its growing importance and Community secondary legislation.

${ }^{29} \mathrm{Id}$.

${ }^{30}$ Christophe Geiger, Intellectual Property Shall be Protected!? - Article 17(2) of the Charter of Fundamental Rights of the European Union: A Mysterious Provision with an Unclear Scope, 31(3) Eur. InTELl. Prop. ReV. 113 (2009); John Griffiths \& Luke McDonagh, Fundamental Rights and European IP Law: The Case of Art 17(2) of the EU Charter, in CONSTRUCTING European Intellectual Property Achievements and New Perspectives (Christophe Geiger ed., 2013); Tuomus Mylly, The Constitutionalization of the European Legal Order: Impact of Human Rights on Intellectual Property in the EU, in Research Handbook on Human Rights and Intellectual Property, supra note 4; Peukert, supra note 4; Husovec, supra note 26; SGANGA, supra note 4.

${ }^{31}$ Peukert, supra note 23, at 142-43; Paul Torremans, Art 17(2), in The EU Charter of Fundamental Rights: A Commentary, supra note 7, at 503; Martin Husovec, The Fundamental Right to Property and the Protection of Investment: How Difficult Is It to Repeal New Intellectual Property Rights? in RESEARCH HANDBOOK OF INTELLECTUAL Property AND InVESTMENT LAW (Christophe Geiger ed., forthcoming 2019).
} 
to advance harmonization goals by declaring national laws incompatible with the safeguards. In other words, the CJEU quickly emancipated Article 17(2) from A1P1, although still building upon its foundations and drawing on its methodology. The emancipation process was observed by a number of scholars. ${ }^{32}$ In a way, this was to be expected given that, unlike the ECtHR, the $\mathrm{CJEU}$ is at the same time interpreting secondary EU law, which includes an increasing number of laws relating to intellectual property rights.

The relationship between the ECtHR and the CJEU is fairly complex. ${ }^{33}$ For the purposes of this Article, it suffices to say that the ECtHR serves as a minimum standard of protection available within the EU Charter. ${ }^{34}$ The EU Charter may go beyond this standard. At the same time, interpretation of parallel provisions in the Convention provided by the ECtHR is one of the crucial sources of interpretation, ${ }^{35}$ next to "the constitutional traditions common to the Member States." 36 We will return to the latter concept at the end of this Article.

At the moment, the exact contours of Article 17(2) are being tested before the courts. As the standardized tobacco packaging litigation mentioned above shows, its guarantees are being increasingly invoked by firms in high profile cases to challenge various pieces of legislation. Two important aspects are in dispute: (1) The extent of protection offered by Article 17(2), and (2) The nature of IP rights. The first question concerns whether Article 17(2) offers more protection than A1P1 and goes to the core of the current article. In the litigation about standardized packaging of tobacco products, plaintiffs invoked enhanced protection of their IP rights through Article 17(2), which should have prevented legislative change. Their argument was that the essence of the right is protected much more strongly under the EU Charter than under A1P1. The second question-concerning a dispute about the very nature of IP rights-is beyond the scope of this Article. ${ }^{37}$

\section{Methodology of Conflict Resolution}

The proportionality test is the main tool for the resolution of constitutional conflicts. Article 52(1) of the EU Charter provides an overarching description of the mechanism, according to which, "[a]ny limitation on the exercise of the rights and freedoms recognised by this Charter must be provided for by law and respect the essence of those rights and freedoms." Any limitations "may be made only if they are necessary and genuinely meet objectives of general interest recognised by the Union or the need to protect the rights and freedoms of others." This principle is extensively used in IP case-law, which keeps repeating the mantra of "fair balance," although not always referring back to Article 52 of the EU Charter.

\footnotetext{
${ }^{32}$ See Mylly, supra note 30, at 106, 119 (cautioning that nowadays Article 17(2) assumes roles that are not present under Article 1 of the First Protocol); Jonathan Griffiths, Constitutionalising or Harmonising? The Court of Justice, the Right to Property and European Copyright Law, 38 Eur. L. REv. 65 (2013) (observing a pro-harmonization bias in the case-law); Husovec, supra note 26, at 241, 257 (suggesting that the latest case law of the Court shows a marked departure from the ECHR origins, pointing to emergence of positive obligations under Article 17(2) that occasionally challenge even previously settled readings of the secondary Union law).

${ }^{33}$ See ECJ, Case C-2/13, Avis 2/13, ECLI:EU:C:2014:2454, Judgment of Dec. 18, 2014. See also Gráinne de Búrca, After the EU Charter of Fundamental Rights: The Court of Justice as a Human Rights Adjudicator? 20(2) MAASTRICHT J. EUR. \& COMP. L. 168 (2013).

${ }^{34}$ Charter of Fundamental Rights of the European Union art. 53, Dec. 18, 2000, 2000 O.J. (C 364$) 21$ [hereinafter EU Charter].

${ }^{35}$ Id. art. 52(3). See also Peers \& Prechal, supra note 7, at 1460.

${ }^{36} \mathrm{EU}$ Charter art. 52(4).

${ }^{37}$ More specifically, the question is to what extent IP rights lend their holders not only negative rights to exclude others under some circumstances, but also some positive market expectations. This aspect was at the center of the standardized packaging litigation too, as it was disputed to what extent trademark rights imply access to the market using the registered signs.
} 
Historically, the CJEU has already emphasized the non-absolute nature of IP rights in $1998 .^{38}$ In Metronome Musik, it held that "the freedom to pursue a trade or profession, and likewise the right to property, form part of the general principles of Community law." ${ }^{39}$ In the same breath, the Court also highlighted that "those principles are not absolute but must be viewed in relation to their social function." ${ }^{\prime 0}$ Post-Lisbon Treaty, this holding was confirmed in a widely-cited paragraph in Scarlet Extended, in which the Court held that " $\mathrm{t}]$ here is, however, nothing whatsoever in the wording of [Article 17(2)] or in the Court's case-law to suggest that that right is inviolable and must for that reason be absolutely protected." ${ }^{\prime 1}$ IP rights are therefore without doubt not absolute rights, and must always be balanced with other rights and interests.

\section{Theories of Essence}

In the literature and case-law, the extent to which the reference to "the essence" in the EU Charter implies a separate test to the proportionality requirement has been extensively debated. ${ }^{42}$ One can distinguish two main views about the interaction between essence and proportionality as limiting principles.

According to the first view - the relative theory - proportionality is the only analytical framework for any type of interferences, including those that touch the essence of rights. Every interference is thus subject to a proportionality exercise. Interference with essence only corresponds to a particularly severe type of interference which can, however still be justified. As explained by Christoffersen, this view adds nothing but rhetoric to the weighing and balancing of interests. ${ }^{43}$

According to the second view-the absolute theory-interfering with the essence is to be distinguished from other interferences. Unlike an ordinary interference, interference with the essence of a right is absolutely prohibited under all circumstances. Therefore, no proportionality exercise can be undertaken in that context. It constitutes a special case within the group of all interferences. Of course, overlaps among the rights or their cores can exist, such as when the right to property overlaps with the right to effective remedy.

The concept of the essence of rights has its origin in Article 19(2) of the German Constitution from 1949. It has also appeared in the jurisprudence of the European Court of Human Rights (ECtHR) ${ }^{44}$ Although the Convention does not explicitly refer to it, the Court has made a number of references to it over the years. ${ }^{45}$ In Matthews v. the United Kingdom, the Court considered the unavailability and denial of the exercise of a fundamental right to vote to constitute a breach of the essence of that right. ${ }^{46}$ Similarly, the essence of the right is also mentioned in the UN Human

\footnotetext{
${ }^{38}$ Metronome Musik, Case C-200/96.

${ }^{39}$ Opinion of Advocate General Tesauro, supra note 6, at para. 21, fn. 19.

${ }^{40}$ Metronome Musik, Case C-200/96 at para. 21 (emphasis added).

${ }^{41}$ ECJ, Case C-70/10, Scarlet Extended, ECLI:EU:C:2011:771, Judgment of Nov. 24, 2011, para. 43.

${ }^{42}$ Peers \& Prechal, supra note 7, at 1476, 1480 (viewing both tests as part of the balancing exercise and noting that the caselaw usually makes no attempt to separate the tests/elements because they are hard to separate in practice).

${ }^{43}$ Jonas Christoffersen, Human Rights and Balancing: The Principle of Proportionality, in RESEARCH HANDBOOK ON HUMAN Rights AND INTELlectual Property, supra note 4, at 19, 25-27.

${ }^{44}$ Belgian Linguistic Case, 1 EHRR 252 (1968); For an in-depth study, see ECKART KLEIN, WESENSGEHALT vON MensChenrechten [Essence of Human Rights] (2005).

${ }^{45}$ Golder v. United Kingdom, App. No. 4471/70 (Feb. 21, 1975), http://hudoc.echr.coe.int/eng?i=001-57496; Prince HansAdam II of Liechtenstein v. Germany, App. No. 42527/98 (July 21, 2001), http://hudoc.echr.coe.int/eng?i=001-59591; Campbell v. United Kingdom, App. No. $7511 / 76$ (Feb. 25, 1982), http://hudoc.echr.coe.int/eng?i=001-57455.

${ }^{46}$ Matthews v. United Kingdom, App. No. 24833/94, paras. 63-65 (Feb. 18, 1999), http:hudoc.echr.coe.int/eng?i=00158910.
} 
Rights Committee's General Comment 27 with respect to the International Covenant on Civil and Political Rights. It is also present in the national constitutional traditions of some EU Member States. ${ }^{47}$

Although the CJEU recognized the fundamental rights to property as early as the $1970 \mathrm{~s},{ }^{48}$ the explicit reference to their essence only appears much later. In Nold, the Court speaks of a right's "substance," which must be left untouched. ${ }^{49}$ In Karlsson and Kadi, the Court speaks of the "very substance" when emphasizing the need to avoid undermining it. ${ }^{50}$ Post-Lisbon, in Trabelsi, ${ }^{51}$ the General Court equates both concepts with "essence" under Article 52 of the EU Charter. Very recently, according to some scholars, the CJEU hinted at a separate test following the absolute theory of essence. In their view, as expressed in a series of recent decisions-Sky Österreich (2013) ${ }^{52}$ Digital Rights Ireland (2014), ${ }^{53}$ and most importantly, Schrems $(2015)^{54}$ - the Court analytically distinguishes between core interferences ${ }^{55}$ and other ordinary interferences that are subject to the proportionality exercise. ${ }^{56}$ Brkan and Ojanen argue in favor of this reading. ${ }^{57}$ In other cases during the same period, the CJEU refrains from such separation and signals the opposite. ${ }^{58}$ The general situation in the case-law is therefore inconclusive, at best. As this Article will show, the situation in intellectual property, if viewed in context, is even less suggestive of any absolutist theory of essence.

The absolutist reading of core rights would translate to the following application scheme. First, the Court reviews whether an interference is "provided by the law." If the answer is positive, the Court reviews whether the interference touches the core of a particular fundamental right. If this is the case, the analysis ends here and the interference is declared inadmissible. If it does not touch the core, the Court proceeds to the proportionality analysis. The Court can then declare these "ordinary" interferences justified or not, depending on their objectives, necessity, and adequacy. All of this is assessed against the factual background. The context thus matters for both tests, although in different ways.

In the following sections, I will outline the jurisprudential status quo regarding the essence of intellectual property rights before the ECtHR and CJEU, ${ }^{59}$ and then explore how a potential

\footnotetext{
${ }^{47}$ See Gerhard van der Schyff, Cutting the Core of Conflicting Rights: the Question of Inalienable Cores in Comparative Perspective, in Conflicts with Fundamental Rights 131 (Eva Brems ed., 2008); Maja Brkan, The Concept of Essence of Fundamental Rights in the EU Legal Order: Peeling the Onion to its Core, 14(2) Eur. Const. L. Rev. 332 (2018).

${ }^{48}$ ECJ, Case C-4/73, Nold KG v. Commission, ECLI:EU:C:1974:51, Judgment of May 14, 1974; ECJ, Case C-44/79, Hauer v. Land Rheinland-Pfalz, ECLI:EU:C:1979:290, Judgment of Dec. 13, 1979.

${ }^{49}$ Nold KG, Case C-4/73 at para. 14 ("[W]ithin the community legal order it likewise seems legitimate that these rights should, if necessary, be subject to certain limits justified by the overall objectives pursued by the Community, on condition that the substance of these rights is left untouched.").

${ }^{50}$ ECJ, Case C-292/97, Karlsson, ECLI:EU:C:2000:202, Judgment of Apr. 13, 2000, para. 45; ECJ, Joined Cases 402 \& 415/05, Kadi v. Council and Commission, ECLI:EU:C:2008:461, Judgment of Sept. 3, 2008, para. 355.

${ }^{51}$ ECJ, Case T-187/11 Trabelsi v. Council, ECLI:EU:T:2013:273, Judgment of May 28, 2013, para. 81.

${ }^{52}$ ECJ, Case C-283/11, Sky Österreich, ECLI:EU:C:2013:28, Judgment of Jan. 22, 2013, para. 48.

${ }^{53}$ ECJ, Case C-293/12, Digital Rights Ireland, ECLI:EU:C:2014:238, Judgment of Apr. 8, 2014 paras. $39,45$.

${ }^{54}$ ECJ, Case C-362/14, Schrems, ECLI:EU:C:2015:650, Judgment of Oct. 6, 2015, para. 94.

${ }^{55}$ Hans D. Jarass, Charta der Grundrechte der Europäischen Union: GRCh [Charter of Fundamental Rights OF THE EUROPEAN UNION: GRCH] art. 17, paras. 28-29 (2016).

${ }^{56} \mathrm{Id}$.

${ }^{57}$ Id.; T Ojanen, Making the Essence of Fundamental Rights Real: The Court of Justice of the European Union Clarifies the Structure of Fundamental Rights under the Charter: ECJ 6 October 2015, Case C-362/14, Maximillian Schrems v Data Protection Commissioner, 12(2) Eur. ConsT. L. REV. 318 (2016); Brkan, supra note 47.

${ }^{58}$ ECJ, Case C-477/14, Pillbox 38, ECLI:EU:C:2016:324, Judgment of May 4, 2016, para. 160.

[A]ccordance with Article 52(1) of the Charter, any limitation on the exercise of the rights and freedoms recognised by the Charter must be provided for by law and respect the essence of those rights and freedoms and, in compliance with the principle of proportionality, must be necessary and actually meet objectives of general interest recognised by the European Union or the need to protect the rights and freedoms of others. (Emphasis added).

${ }^{59}$ See infra Section C.
} 
construction of essence of intellectual property rights could look under the EU Charter. ${ }^{60}$ This will be followed by a brief conclusion summarizing the findings.

\section{Jurisprudence of the ECtHR and CJEU}

Today's IP case-law of the CJEU is dominated by fundamental rights rhetoric. The number of cases which rely on the fundamental rights — including the right to intellectual property - have risen substantially since the Lisbon Treaty entered into force. ${ }^{61}$ Even beforehand, intellectual property rights, as protected interests under general principles, were intermittently present in the case-law concerning free movement of goods and services or competition law. ${ }^{62}$

Analytically, we can categorize the case-law as follows: (1) Situations outside ratione materiaefor example, outside of the remit of a fundamental right to intellectual property, and (2) Conflicts with an interference that might be legitimate or illegitimate. To examine the role of "essence," I separately highlight cases which apply or interpret the notion of the essence of the fundamental right to intellectual property.

\section{Situations Outside Ratione Materiae}

Intellectual property rights are fundamental rights defined by the legislator. ${ }^{63}$ This means that the legislator also defines what falls under its ambit. It does so by two choices: (1) What bears the label of "intellectual property," and (2) What the legislative scope is.

Although there might be little dispute regarding terminology concerning the main intellectual property rights, the qualification of some rights—such as trade secrets—as intellectual property might be questionable. ${ }^{64}$ The legislative design and definitions influence the extent to which protection would be offered in practice. Naturally, even if protection is not offered by Article 17(2), it might be offered by Article 17(1). Furthermore, the CJEU could decide to create its own autonomous notion of "intellectual property." Yet, doing so would prompt questions about the definitional factors to be used.

\footnotetext{
${ }^{60}$ See infra Section D.

${ }^{61}$ ECJ, Case C-484/14, McFadden, ECLI:EU:C:2016:689, Judgment of Sept. 15, 2016; ECJ, Case C-160/15, GS Media, ECLI: EU:C:2016:644, Judgment of Sept. 8, 2016; ECJ, Case C-201/13, Deckmyn, ECLI:EU:C:2014:2132, Judgment of Sept. 23, 2014; ECJ, Case C-314/12, UPC Telekabel Wien, ECLI:EU:C:2014:192, Judgment of Mar. 27, 2014; ECJ, Case C-360/10, SABAM v. Netlog, ECLI:EU:C:2012:85, Judgment of Feb. 16, 2012; Luksan, Case C-277/10; ECJ, Case C-145/10, Painer, ECLI:EU: C:2011:798, Judgment of Dec. 1, 2011; Scarlet Extended, Case C-70/10; ECJ, Case C-580/13, Coty Germany, ECLI:EU: C:2015:485, Judgment of July 16, 2015; ECJ, Case T-542/10, XXXLutz Marken v. OHIM, ECLI:EU:T:2012:294, Judgment of June 13, 2012; ECJ, Case T-526/09, PAKI Logistics v. OHIM, ECLI:EU:T:2011:564, Judgment of Oct. 5, 2011; ECJ, Case C-170/13, Huawei Technologies, ECLI:EU:C:2015:477, Judgment of July 16, 2015; ECJ, Case C-147/13, Spain v. Council, ECLI:EU:C:2015:299, Judgment of May 5, 2015; ECJ, Case C-34/10 Brüstle, ECLI:EU:C:2011:669, Judgment of Oct. 18, 2011; ECJ, Case C-469/17, Funke Medien NRW, ECLI:EU:C:2018:870; Pelham, Case C-476/17; ECJ, Case C-516/ 17, Spiegel Online.

${ }^{62} \mathrm{See}$, for the overview, Husovec, Intellectual Property Rights and Integration by Conflict: The Past, Present and Future, in 18 Cambridge Yearbook of European Legal Studies 239-69 (2016).

${ }^{63}$ The CJEU so far has not yet had a chance to fully expand on the legislator's role in defining the rights.

${ }^{64}$ It is not self-evident that they constitute a form of 'intellectual property'. Their treatment in the case-law is mixed at best. See Lionel Bentley, Trade Secrets, in Concepts of Property in Intellectual Property Law 60 (Howe \& Griffiths eds., 2013) (arguing that trade secrets are predominantly being accepted as "intellectual property" but not "property"). The only hint at possible protection by Article 17(2) is ECJ, Case C-1/11, Interseroh Scrap \& Metals Trading, ECLI:EU:C:2012:194, Judgment of Mar. 29, 2012, para. 43. CJEU case-law broadly accepts that the rights are protected under general principles of EU law. See, e.g., ECJ, Case C-450/06, Varec, ECLI:EU:C:2008:91, Judgment of Feb. 14, 2008, para. 49). Still, the specific rights protected are less clear. See also Commission Communication Regarding Guidance on Certain Aspects of Directive 2004/ 48/EC of the European Parliament and of the Council on the Enforcement of Intellectual Property Rights, COM (2017) 708 final (Nov. 29, 2017).
} 
As regards the legislated scope, the statutory design might prevent interferences from arising. For instance, in Netherlands $v$ European Parliament ${ }^{65}$ the CJEU found that imposing exclusive rights on bio-technological inventions through the patent system does not interfere with human dignity. ${ }^{66}$ Due to the way in which the patent system operates, the CJEU saw no need for individual balancing of human dignity and property rights. The CJEU concludes that from the design of the Directive, it is clear that "as regards living matter of human origin, the Directive frames the law on patents in a manner sufficiently rigorous to ensure that the human body effectively remains unavailable and inalienable and that human dignity is thus safeguarded." ${ }^{\prime \prime}$ The Court explained that an element of the human body may be part of a product that is patentable but that it may not, in its natural environment, be patented itself. ${ }^{68}$

Hence the very design of the patent law mitigates the conflict. The ability to obtain patents for technical inventions grounded in the human body thus, in the Court's view, does not mean a possibility to appropriate them. This conclusion arguably rests on the actual design of the patent system which filters such effects through a set of criteria-such as novelty, inventive step, industrial application, and a set of patentability exclusions. ${ }^{69}$ As the Court puts it, "the protection envisaged by the Directive covers only the result of inventive, scientific or technical work, and extends to biological data existing in their natural state in human beings only where necessary for the achievement and exploitation of a particular industrial application." 70 This highlights the fact that the actual legislative design of rights predetermines not only the scope of the conflict, but also the very existence of one in the first place. This issue is also crucial for the debate about positive and negative rights allegedly implied in trademark law-an issue that is beyond the scope of this article.

Outside of ratione materiae, there are cases where legitimate expectation is missing, although some form of interests exist. In the spirit of $\mathrm{A} 1 \mathrm{P} 1,{ }^{71}$ it is clear that, according to the CJEU case-law,

the protection of the right to property afforded by Article 17 of the Charter does not apply to mere commercial interests or opportunities, the uncertainties of which are part of the very essence of economic activity, but applies to rights with an asset value creating, under the legal system, an established legal position enabling the holder to exercise those rights autonomously and for his benefit. ${ }^{72}$

The judgment in Sky Österreich shows that even legislation permitting competitors to re-use short extracts from each other's licensed broadcasts for the purpose of short news coverage might not qualify as interference with "property." Here, the CJEU concluded that "[a]n economic operator ... which ... has acquired exclusive broadcasting rights by means of a contract . . . cannot, in the light of European Union law, rely on an acquired legal position, protected by Article 17(1) of the Charter."73 Nonetheless, the Court then granted the broadcasters protection under the somewhat weaker right to conduct a business as enshrined in Article $16 .{ }^{74}$ These types of qualification problems can arise

\footnotetext{
${ }^{65}$ ECJ, Case 3-77/98, Netherlands v. Parliament \& Council, ECLI:EU:C:2001:523, Judgment of Oct. 9, 2001.

${ }^{66} I d$. at para. 69.

${ }^{67} \mathrm{Id}$. at para. 77.

${ }^{68} I d$. at para. 74 .

${ }^{69} I d$. (discussing these elements).

${ }^{70} \mathrm{Id}$. at para. 75 .

${ }^{71}$ ECJ, Case C-398/13, Inuit Tapiriit Kanatami v. Commission, ECLI:EU:C:2015:535, Judgment of Sept. 3, 2015 , para. 61.

${ }^{72} I d$. at para. 60 .

${ }^{73}$ Sky Österreich, Case C-283/11 at para. 39

${ }^{74} I d$. at para. 31 .
} 
in the constitutional context, ${ }^{75}$ especially when derivative right holders-who only receive rights by assignments or licenses-wish to invoke the interests of original right holders, for example, authors. $^{76}$

In the ECtHR case-law, the cases which fall outside of ratione materiae are usually cases where the plaintiff cannot prove that an intellectual property right ever existed in the national law, or otherwise ceased to exist there. ${ }^{77}$

\section{Interferences that Need Justification}

Similarly to A1P1, Article 17(1) recognizes two main types of interferences: Control of use of property, and, more seriously, deprivation of property. ${ }^{78}$ The ECtHR also recognizes a residual category of other types of interferences ${ }^{79}$ which might also be available under the EU Charter, if necessary. ${ }^{80}$ Deprivation, unlike control of use of property, requires compensation to be justified. Other types of interferences might also demand compensation as a matter of proportionality, but not as a strict rule. ${ }^{81}$ Deprivation, according to the ECtHR's case-law, means a full "transfer of property" to another person, be it a public authority or private party. It might take the form of a legislative or other public intervention. Cases in which the property stays with the victim and is only emptied of its content, sometimes qualify as "de facto deprivations," which are then treated in the same way as deprivations under the ECtHR. ${ }^{82}$ The CJEU does not recognize this category.

In the great majority of cases, IP rights merely experience "ordinary" clashes with other rights and interests. The three main categories of case-law are conflicts between IP rights and either: (1) Other fundamental rights ${ }^{83}$; (2) The principle of free movement of goods and services ${ }^{84}$; or

\footnotetext{
${ }^{75}$ Similarly to Sky Österreich, the Court found in the Winzersekt case that taking away a sign from the public domain and assigning rights to geographical indications to it cannot be regarded as an infringement of a right to property because "prior to the adoption of the regulation, all producers of sparkling wines were entitled to [its] use." Therefore, the Court tests the interference under the right to conduct a business. ECJ, Case C-306/93, SMW Winzersekt v. Land Rheinland-Pfalz, ECLI:EU: C:1994:407, Judgment of Dec. 13, 1994, paras. 23-24.

${ }^{76}$ See Bundesverfassungsgericht [BVERFGE] [Federal Constitutional Court] Case No. 1 BvR 1213/16, para. 28, (Apr. 18, 2018) ("Gesetzliche Vergütungsansprüche sind vom Gesetzgeber ausschließlich zugunsten der Urheber und nicht der Inhaber von abgeleiteten Nutzungsrechten wie dem Verlagsrecht vorgesehen") ["Statutory remuneration claims are provided by the legislator exclusively for the benefit of the authors and not the holders of derived rights of use such as the publishing right"].

${ }^{77}$ Dima, App. No. 58472/00 (refusing to recognize copyright in a work for the state); University of Illinois Foundation v. the Netherlands, App. No. 12048/86 (1998) (Eur. Comm'n on H.R.).

${ }^{78} \mathrm{See}$ EU Charter, art. 17(1); European Convention on Human Rights Protocol 1 art. 1, Nov. 4, 1950, Europ.T.S. No. 5, 213 U.N.T.S. 221.

${ }^{79}$ See Sporrong \& Lönnroth v. Sweden, App. No. 7151/75, (Sept. 23, 1982), http://hudoc.echr.coe.int/eng?i=001-57580.

${ }^{80}$ Steve Peers \& Sascha Prechal, Article 52-Scope of Guaranteed Rights, in THE EU CHARTER OF FundamENTAL RIGHTS: A COMMENTARY, supra note 7 , at 476, 486.

${ }^{81} I d$. at 479 .

${ }^{82}$ See Sporrong \& Lonnroth, App No. 7151/75 at para. 63.

${ }^{83}$ See Husovec, supra note 26.

${ }^{84}$ See, e.g., ECJ, Case C-15/74 Centrafarm BV v. Sterling Drug, ECLI:EU:C:1974:114, Judgment of Oct. 31, 1974, para. 9 (regarding patents); ECJ, Case C-258/78, Nungesser v. Commission, ECLI:EU:C:1982:211, Judgment of June 8, 1982, paras. 8, 35 (regarding trademarks and plant varieties, respectively); ECJ, Case C-144/81, Keurkoop v. Nancy Kean Gifts, ECLI:EU: C:1982:289, Judgment of Sept. 14, 1982, para. 14 (regarding designs); ECJ, Case C-317/91, Deutsche Renault v. AUDI, ECLI:EU:C:1993:908, Judgment of Nov. 30, 1993, para. 17 (regarding non-registered trademarks); ECJ, Case C-55/80, Musik-Vertrieb Membran GmbH v. GEMA, ECLI:EU:C:1981:10, Judgment of Jan. 20, 1981, para. 12 (regarding copyrights); ECJ, Case C-388/95, Belgium v. Spain, ECLI:EU:C:2000:244, Judgment of May 16, 2000, para. 54 (regarding designations of origin); ECJ, Case C-3/91, Exportur v. LOR \& Confiserie du Tech, ECLI:EU:C:1992:420, para 23 (regarding geographical indications).
} 
(3) Provisions of competition law. ${ }^{85}$ I have shown in my earlier work ${ }^{86}$ that the large corpus of case-law shows a slight disconnect between pre-Charter jurisprudence that mostly concerned the second and third category of conflicts, and the newest case-law that centers on the first category. In this part, I will therefore make some focused observations based on this previous work.

First, since Scarlet Extended, ${ }^{87}$ the CJEU has highlighted that intellectual property rights are not absolute and must always be balanced with other interests. Over the years, the Court held that legislative design of exclusive rights must be interpreted in light of fundamental rights, such as freedom of expression. ${ }^{88}$ This also applies to exceptions and limitations. ${ }^{89}$ At the moment, there are three pending cases which will likely define the exact role that other fundamental rights play in judicial interpretations - especially when the legislative design of intellectual property rights potentially neglects other fundamental rights. ${ }^{90}$ Advocate General Szpunar, in Pelham and Spiegel Online suggests that fundamental rights ought to play "a sort of ultima ratio [role] which cannot justify departing from the wording of the relevant provisions except in cases of gross violation of the essence of a fundamental right." 11 In other words, only violations of the essence of the rights of others, in his view, can justify an intervention by the court into the legislator's broad range of choices.

Given the introduction, it might come as a surprise that the Court only exceptionally refers to notions of use of property in the intellectual property case-law. ${ }^{92}$ Most of the balancing is unstructured, without classifying interferences as "use of property" or "deprivation." The caselaw concerning free movement-which mostly pre-dates the EU Charter-often analyzed cases through the notion of the so called "specific subject matter," which is specific for every right. Its function was to extract the substance of each of the IP rights in the context of balancing. The doctrine of specific subject matter, according to the case-law, "does not guarantee the right holders concerned the opportunity to demand the highest possible remuneration." 93 Any "such remuneration must be reasonable in relation to the economic value of the service provided." In particular, "it must be reasonable in relation to the actual or potential number of persons who enjoy or wish to enjoy the service." ${ }^{4}$ Specific subject matter is equally present in the case-law concerning conflicts with competition law policy. ${ }^{95}$ Surprisingly, however, it plays no role in situations when Article 17(2) faces other fundamental rights.

The Court only occasionally refers to deprivation. Nonetheless, with the exception of Luksan, there appear to be no decisions of the ECtHR or CJEU that would classify an interference with an intellectual property right as deprivation of property. In Tokai, the plaintiffs argued that the prohibition of the use of the word "Tocai" for the description and presentation of certain high-quality Italian wines constitutes a "disproportionate and intolerable interference, impairing the very substance of the fundamental right to property of the economic operators concerned." 96

\footnotetext{
${ }^{85}$ See, e.g., ECJ, Case C-238/87, Volvo v. Veng, ECLI:EU:C:1988:477, Judgment of Oct. 5, 1998; ECJ, Case C-418/01, IMS Health, ECLI:EU:C:2004:257, Judgment of Apr. 29, 2004; ECJ, Case C-241/91, RTE \& ITP v. Commission, ECLI:EU: C:1995:98, Judgment of Apr. 6, 1995; ECJ, Case T-201/04, Microsoft, ECLI:EU:T:2007:289, Judgment of Sept. 17, 2007; ECJ, Case T-167/08, Microsoft, ECLI:EU:T:2012:323, Judgment of June 27, 2012.

${ }^{86}$ Husovec, supra note 26.

${ }^{87}$ Peers \& Prechal, supra note 80 , at 479.

${ }^{88}$ ECJ, Case C-466/12, Svensson, ECLI:EU:C:2014:76, Judgment of Feb. 13, 2004.

${ }^{89}$ Deckmyn, Case C-201/13.

${ }^{90}$ Opinion of Advocate General Szpunar, supra note 15; Opinion of Advocate General Szpunar, Case C-516/17, Spiegel Online (Jan. 10, 2019), http://curia.europa.eu/juris/liste.jsf?language=en\&num=C-516/17; Opinion of the Advocate General Szpunar, supra note 13.

${ }^{91}$ Opinion of Advocate General Szpunar, supra note 15, at para. 98; Opinion of Advocate General Szpunar, supra note 13, at para. 62.

${ }^{92}$ See, e.g, Case C-347/03, Regione autonoma Friuli-Venezia Giulia \& ERSA, ECLI:EU:C:2005:285, Judgment of May 12, 2005.

${ }^{93}$ ECJ, Case C-403/08, Football Association Premier League, Judgment of Oct. 4, 2011, para. 108.

${ }^{94} I d$. at para. 109.

${ }^{95}$ See, e.g., RTE \& ITP, Case C-241/91.

${ }^{96}$ Regione autonoma Friuli-Venezia Giulia \& ERSA, Case C-347/03 at para. 121.
} 
The CJEU rejected this, arguing that because the prohibition does not exclude any reasonable method of marketing the Italian wines concerned, it cannot amount to "deprivation." 7 Similarly, in Planta Fabrik, the CJEU held that a labeling restriction for the outside packaging of tobacco products does not interfere with "the substance of their trade mark rights." Because the proprietors of the trademarks can continue "to make use of them in any way, in particular by wholesale, other than those mentioned in those provisions," such legislative measures cannot qualify as deprivations. ${ }^{99}$ This decision therefore only confirms an earlier, less explicit finding of the Court concerning e-cigarettes, which found that marketing restrictions "in no ways hinder the essence of its property right." 100

Perhaps the most consequential case concerning deprivation of property is Luksan. In this case, the Court actually found that "the fact that national legislation denies [the author] the exploitation rights at issue would be tantamount to depriving him of his lawfully acquired intellectual property right." ${ }^{101}$ Yet, the decision is based on the interpretation of the secondary EU law requiring that rights to exploit a cinematographic work-reproduction right, satellite broadcasting right, etc.vest by operation of law, directly and originally, in the principal director of a film. ${ }^{102}$ As emphasized by the Court, denying these rights

first, would not respect the competence of the European Union in the matter, second, would not be compatible with the aim pursued by Directive 2001/29 and, finally, would not be consistent with the requirements flowing from Article 17(2) of the Charter of Fundamental Rights guaranteeing the protection of intellectual property. ${ }^{103}$

In other words, rather than postulating any core rights that could not be ignored by a legislator, the CJEU in Luksan equates a violation of secondary EU law with a deprivation of possessions in the sense of Article 17(2). ${ }^{104}$ Every violation of secondary EU law as a result of a lack of protection in domestic legislation is thus seen as a deprivation. Had the CJEU based such findings of deprivation on Article 17(2) itself without at the same time finding a violation of secondary EU law, this would have been a clear manifestation of a firm standard that ought to be respected by the Union and national legislators. ${ }^{105}$

In the ECtHR case-law, deprivation was alleged in University of Illinois Foundation $v$ Netherlands, ${ }^{106}$ in which the applicant's patent lapsed due to a failure to pay renewal fees. The applicant complained, arguing that this effectively amounted to deprivation. The European Commission of Human Rights, however, found that restoration had no legal basis in Dutch patent law, and thus was outside ratione materiae. This suggests that there is no inherent right to the preservation of property, irrespective of the legal design, provided that the conditions of maintaining it are reasonable. In Balan Moldova, ${ }^{107}$ the Court dealt with a case in which domestic courts declined to enforce copyright against the unauthorized use of a photograph by the state in identification

\footnotetext{
${ }^{97} I d$. at para. 122 .

${ }^{98}$ ECJ, Case C-220/17, Planta Tabak, ECLI:EU:C:2019:76, Judgment of Jan. 30, 2019, para. 97.

${ }^{99} I d$. at para. 98.

${ }^{100}$ Pillbox 38, Case C-477/14 at para. 164 (confirming AG's opinion in paras. 199, 200).

${ }^{101}$ Luksan, Case C-277/10 at para. 70 .

${ }^{102} I d$. at para. 72 .

${ }^{103} I d$. at para. 71.

${ }^{104}$ Husovec, supra note 26, at 265; See also Henning Grosse Ruse-Khan, Overlaps and Conflict Norms in Human Rights Law: Approaches of European Courts To Address Intersections With Intellectual Property Rights, in RESEARCH HANDBOOK ON Human Rights and Intellectual Property, supra note 4, at 70, 78; Peukert, supra note 23, at 134.

${ }^{105}$ The judgment in Coty Germany-Coty Germany, Case C-580/13 - is a demonstration of an expansive reading of the secondary EU law through the prism of a right to effective remedy, effect utile, and an underlying positive obligation to protect already granted IP rights.

${ }^{106}$ University of Illinois Foundation, App. No. 12048/86.

${ }^{107}$ Bălan, App No. 19247/03.
} 
cards. The ECtHR found a violation but did not qualify it as a deprivation of property. Again, there are other means of exploitation available. In Smith Kline v Netherlands ${ }^{108}$ and SIA AKKA/LAA v Latvia ${ }^{109}$ respectively, the Court upheld the lawfulness of compulsory licenses to patents and the denial of injunctive relief with respect to use of copyrighted works. In both cases, the ECtHR classified the cases as "control of the use of property." The underlying reason in both cases appears to be that although they limit exclusivity, they assure compensation to affected IP holders.

\section{Essence}

There is no systematic use of the concept of "essence" in the intellectual property case-law of the CJEU. The early free movement and competition case-law, as was already mentioned, often refers to "specific subject matter," "very subject matter," or "substance" of a right interchangeably. In these decisions, which often questioned national IP rights from a market freedoms perspective, the Court articulated its view that

the exercise of the right to property and the freedom to pursue a trade or profession may be restricted, provided that any restrictions in fact correspond to objectives of general interest pursued by the European Community and do not constitute in relation to the aim pursued a disproportionate and intolerable interference, impairing the very substance of the rights guaranteed. ${ }^{110}$

To illustrate the use of the concept of "specific subject matter" further, consider the 1988 Volvo case, in which the CJEU held that

[ $\mathrm{t}$ ] he right of a proprietor of a protected design to prevent third parties from manufacturing and selling or importing, without his consent, products incorporating the design constitutes the very subject-matter of his exclusive right. It follows that an obligation imposed upon the proprietor of a protected design to grant to third parties, even in return for a reasonable royalty, a licence for the supply of products incorporating the design would lead to the proprietor thereof being deprived of the substance of his exclusive right, and that a refusal to grant such a licence cannot in itself constitute an abuse of a dominant position. It must however be noted that the exercise of an exclusive right by the proprietor of a registered design in respect of car body panels may be prohibited [as an abuse of dominant position]. ${ }^{111}$

This line of case-law was recently confirmed by Huawei, ${ }^{112}$ in which the Court held that the

need for a high level of protection for intellectual-property rights means that, in principle, the proprietor may not be deprived of the right to have recourse to legal proceedings to ensure effective enforcement of his exclusive rights, and that, in principle, the user of those rights, if he is not the proprietor, is required to obtain a licence prior to any use. ${ }^{113}$

Similarly worded warnings against the "deprivation of protection" are also found in Advocate General Cruz Villalón's opinion in Coty Germany, concerning the right to effective remedy, ${ }^{114}$ and then in McFadden by the Court itself. In Coty Germany, AG Cruz Villalón argued that "it is clear

\footnotetext{
${ }^{108}$ Kline, App. No. 12633/87.

${ }^{109}$ SIA AKKA/LAA, App. No. 562/05.

${ }^{110}$ Metronome Musik, Case C-200/96 at para. 21 (emphasis added).

${ }^{111}$ Volvo, Case C-238/87 at paras. 8-9 (emphasis added).

${ }^{112}$ Huawei Technologies, Case C-170/13.

${ }^{113} I d$. at para. 58 .

${ }^{114}$ Opinion of Advocate General Villalon at paras. 36-39, Case C-580/13, Coty Germany, ECLI:EU:C:2015:243 (July 16, 2015), http://curia.europa.eu/juris/liste.jsf?num=C-580/13.
} 
that the essence of the rights would not be respected if the national legislation at issue resulted in the frustration of the right of any holders of intellectual property rights to obtain protection from the courts." 115 In McFadden, the Court held that "[s]ince the two other measures have been rejected by the Court, to [reject the third one] would thus be to deprive the fundamental right to intellectual property of any protection, which would be contrary to the idea of a fair balance." 116 Although here the essence is used in the context of intellectual property disputes, in both cases it mostly concerns the right to an effective remedy and effet utile of the Union law.

\section{Interim Conclusions}

Based on the above analysis, we can make a number of observations. First, the notion of "essence" is hardly applied in the context of intellectual property rights. Instead, the older and newer caselaw sometimes uses words such as "substance," "specific subject matter," and "very subject matter" to identify the crucial features of the legislative design of IP rights. In the enforcement case-law, the CJEU also refers to "deprivation of protection," which is interlinked with essential objectives of these rights.

Second, any reference to essence in the case-law of the CJEU only points towards a higher level of scrutiny, but not towards an untouchable core of rights that may not be abolished by the legislator. Indeed, Scarlet Extended stresses that IP rights are never absolute. Volvo illustrates this interplay well. The CJEU itself reminds us that while exclusivity is at the core of design rights, it might be limited by competition law in some circumstances. Therefore, rather than drawing any red lines for the legislator, the Court highlights that certain subsets of balancing exercises should not be taken lightly, perhaps because they constitute a more serious type of limitation.

Third, on its own, Article 17(2) is void of any inviolable core understood as a red line which cannot be bridged by any considerations of proportionality. It is empty of any guarantees going beyond an obligation to avoid arbitrary interferences and potentially to fairly compensate in case of unfavorable changes. Different legislative choices - for example, new rights for press publishers, which are protected by Article 17(2) of the EU Charter-do have their essence, substance, or specific subject matter. Nonetheless, there is nothing in the case-law that would suggest that some elements of these rights constitute a hard core, as postulated by the absolute theories of essence.

As a consequence, the main paradigm of the constitutional protection of intellectual property rights on the EU level clearly remains that of proportionality, which allows entitlements to be entirely abolished at the will of the legislator, subject to the Charter safeguards. Dignitary non-economic aspects of intellectual property rights find their protection under different provisions of the EU Charter.

\section{Constructing the Essence of IP Rights}

One can argue that even if the CJEU recognized no hard core of Article 17(2) as of now, it might do so in the future. It could rely on the common constitutional traditions of the Member States. This supposition prompts two obvious questions. First, what is the relationship between any alleged hard or inviolable core and safeguards against deprivation? Second, what are the common constitutional traditions of Member States?

\section{Essence vs Deprivation}

Any inviolable core of Article 17(2) would inevitably limit the ability of the states to interfere by depriving individuals of property. Situations in the hard core would have to be cases where no

\footnotetext{
${ }^{115} I d$. at para. 39.

${ }^{116} \mathrm{McF}$ adden, Case C-484/14 at para. 98.
} 
compensation can be offered to offset the interference because taking away of rights is always considered disproportionate. As stated earlier, we see no such case-law before the ECtHR or CJEU at this point. Instead, we see the CJEU trying to identify essential features of the IP design, in order to signal when the limitation of the use of property is nearing deprivation. The Court's use of its "deprivation of protection" concept suggests that under some circumstances, the Court could employ logic similar to the ECtHR's concept of "de facto deprivation of property" by holding that a deprivation of protection of an unprotected right could trigger compensation requirements. Nonetheless, the use of this phrase does not suggest that the Court would be setting boundaries within which legislators are permitted to act. After providing compensation which respects the criteria of Article 17(1), it is hard to see any further restraints on the legislator in the case-law.

Even looking at Luksan, the only case that found right holders to be deprived of their intellectual property by national law, it is clear that this outcome was preconditioned on the finding of a violation of secondary EU law. Yet, AG Szpunar's proposals in Pelham and Spiegel Online suggest that at least as far as other fundamental rights are concerned-if accepted by the Court-the "gross violation of essence" per se should define the need of the Court to act as a constitutional court and correct the legislator's design. This, however, does not mean by itself that the Court would subscribe to the absolute theory of essence. ${ }^{117}$ In any case, the role and scope of essence seems far from clearly settled.

In the next section, I will look at how essence is understood under different national legal systems and their shared constitutional traditions of international human rights law.

\section{Examples of Constitutional Traditions}

Providing an exhaustive survey of national traditions is beyond the scope of this article. Instead, I attempt to demonstrate how some national courts - as opposed to supranational courts-operate with the concept of essence of intellectual property rights. I do not claim these approaches to be representative of the whole of the EU in any way. My analysis proceeds in the following steps. First, I explain how the CJEU case-law described above was received before the English courts. Second, I contrast this with the traditional German approach to the protection of intellectual property rights under their property clause. Third, I compare the two approaches with Slovakian constitutional doctrine that seems to sit somewhere in between the two, drawing inspiration from other sources of international human rights law, in particular the ICESCR.

\section{United Kingdom}

One of the most direct attempts to rely on the argument of an untouchable core of intellectual property rights is found in the United Kingdom. In litigation concerning standardized tobacco packaging, ${ }^{118}$ tobacco companies argued that their trademark rights were being unjustifiably interfered with. These laws essentially restricted the ability of firms to advertise their brands. The manufacturers could still place the trademark upon the products and thus communicate their identities to consumers, but the manner in which the name could be used became highly regulated in order to strip away as much of the attractiveness of the advertising as possible. Among many arguments, the tobacco firms viewed such restrictions as de facto expropriation of their trademarks. ${ }^{119}$ They argued that the disputed Regulations

impair or affect the "essence" of their property rights and that as such the proportionality test is irrelevant and the Regulations are illegal because of Article 52 of the Fundamental Charter

\footnotetext{
${ }^{117}$ British American Tobacco v. Secretary of State for Health [2016] EWHC (QB) 1169 [270].

${ }^{118} I$ d.; British American Tobacco v. Secretary of State for Health [2016] EWCA (Civ) 1182.

${ }^{119}$ British American Tobacco, EWHC (QB) 1169 at para. 82.
} 
which (they argue) goes (well) beyond the level of protection provided for in A1P1 ECHR and renders illegal any interference with the essence of a fundamental right. ${ }^{120}$

In summarizing their argument, the tobacco companies stated: "In other words no legislation can interfere with a fundamental right to the extent that it impairs its substance even if that interference would otherwise be proportionate." 121 As the Court summarized this, "[t]he practical upshot of this submission was that even if the Regulations were proportionate, because they impaired the essence of the trademarks they were still in breach of Article 17."122

Because the "essence" argument was crucial, Article 17(2) received a fair amount of attention. In his first instance judgment, Justice Green rejected the claim that the governmental regulation amounted to deprivation of property. Instead, he classified it as a form of property control in the sense of A1P1, arguing that title to the rights at issue remains in the hands of the tobacco companies and that the laws curtail the use that can be made of those rights, but they are not expropriated. ${ }^{123}$ Therefore, no compensation needs to be offered by the state. Faced with the argument that Article 17(2) of the EU Charter offers more protection than ECtHR, the judge concluded the following: ${ }^{124}$

I have serious doubts about this analysis and especially the extreme interpretation given to the concept of respecting the essence of the right by the Claimants. Their argument assumes two propositions, neither of which in my view makes legal sense. First, it assumes that each and every fundamental right in the Charter (which is intended to mirror the ECHR) has an absolute and untouchable limit, even when it does not have such a limit in the ECHR. Secondly, it assumes that if on the application of the proportionality test the result is that a measure is proportionate, i.e. (a) suitable relative to its legitimate objective (b) necessary in the sense of being the least intrusive measure and (c) fair in the sense of striking a fair balance between competing interests, that it is still unlawful because the essence of the Claimants' interest (that has already been fairly balanced and found wanting) is impaired. Such a result is legal nonsense.

The Court found this "system of inviolable rights" difficult to understand, in particular because it is not clear how "conflicting fundamental rights are reconciled or how or why EU law would take this illogical and counter-intuitive position."125

Despite this, the judge then took an extraordinary step. Because "the issue is not free from doubt and the terminology used by the Court of Justice has lacked conceptual precision," ${ }^{126}$ he decided to proceed with his legal analysis on the assumption that inviolable core rights might exist. Perhaps unsurprisingly, he found no interference with the "essence" of trademark holder's rights. In order to flesh out the core of trademark rights, the judge inspected the legislative design and case-law of trademark law. Here the tobacco companies had to convince the judge that they not only have a negative right to prohibit use of their signs, but also a positive right to exploit such signs on the market. Both Justice Green and the then appellate judges rejected this idea. In their view, even with an obligation to use a trademark in order to not lose it, trademark rights do not imply positive rights to introduce associated products to the market. ${ }^{127}$ Hence, there can be no violation of the core.

Some months later, in a different case with a similar set-up, the CJEU itself found no violation of the trademark holders' rights. ${ }^{128}$ Although the Court did not speak of "essence," it rejected any

\footnotetext{
${ }^{120} I d$. at para. 270.

${ }^{121} I d$. at para. 819.

${ }^{122} I d$. at para. 820

${ }^{123} \mathrm{Id}$. at para. 38.

${ }^{124} I d$. at para. 825 .

${ }^{125} \mathrm{Id}$. at para. 829 .

${ }^{126} I d$. at para. 831 .

${ }^{127}$ British American Tobacco, EWCA (Civ) 1182 at para. 121.

${ }^{128}$ Planta Tabak, Case C-220/17.
} 
deprivation arguments, thereby agreeing with the Advocate General Saugmandsgaardøe, ${ }^{129}$ and implicitly classifying the interference as control of use of property. ${ }^{130}$

\section{Germany}

The German Basic Law, Grundgesetz (“GG”), does not explicitly mention IP rights. Nevertheless, the case-law which has developed over the years recognizes it as one of the protected interests under Article $14 \mathrm{GG}$, which protects property in general. ${ }^{131}$ In addition, the Basic Law contains an essence (Wesensgehalt) clause in Article 19(2) GG, which requires that "[i]n no case may the essence of a basic right be affected."

In the 1971 Schulbuchprivileg decision, the German Constitutional Court laid the ground for constitutional protection of IP rights. The dispute centered on the question of whether German copyright law may contain an exception that allows license-free and royalty-free copying and distribution of works for educational purposes in schools and churches. Although the newly legislated exception only perpetuated the legal situation that had existed in Germany for decades, ${ }^{132}$ the authors argued that it was unconstitutional. In their view, it violated the author's right to property under Article 14 GG and Article 27 of the Universal Declaration of Human Rights. The government's argument was that the copyright law is to be designed primarily by the German legislator, and that authors who inherently build on works of others essentially owe this to the public. Moreover, the government argued that the exception cannot constitute deprivation of property because authors never had a right to authorize these uses in the past.

The Court held that constitutional protection did not imply that appropriation of any form must be attributed to right holders. ${ }^{133}$ This is because "in defining the content of copyright in line with Article 14 GG, [the legislator] should formulate provisions that guarantee the compatibility of the exploitation of the work with the nature and social relevance of the right."134 The legislator "is not only obliged to protect the interests of the individual, but also to limit her rights to the extent necessary to pursue the public good." ${ }^{135}$ When looking at the case at hand, the Court identified the allocation of proprietary interests originating from an author's creative contributions and their freedom to decide how to use them as the core of the copyright law. ${ }^{136}$

The German Constitutional Court eventually found that the statutory exception did violate Article 14 GG. Thereby, any potential infringement of Article 27 of the Universal Declaration

${ }^{129} I d$. at para. 54 .

Even if the Court finds that a trade mark does confer a positive right of that nature on its proprietor and that Article 13(1)(c) of Directive 2014/40 entails a restriction on that right, that article must, to my mind, be seen as regulating use of the trade marks in question (Article 17(1), third sentence of the Charter) instead of as a deprivation of those rights (Article 17(1), second sentence of the Charter), and it neither casts doubt on the validity of those trade marks nor prevents them from being used other than on the packaging of tobacco products. Nor does Article 13(1)(c) of Directive 2014/40 impair the very substance of those rights. That article in fact merely prevents the elements that it lists from being included in those marks. Manufacturers can still distinguish their products by using other signs. The function of trade marks of indicating origin is therefore not adversely affected.

${ }^{130} I d$. at para. 96.

${ }^{131}$ Bundesverfassungsgericht [BVERFGE] [Federal Constitutional Court] 1971, 31 BVerfGE 229; Bundesverfassungsgericht [BVERFGE] [Federal Constitutional Court] 1971, 31 BVerfGE 248; Bundesverfassungsgericht [BVERFGE] [Federal Constitutional Court] 1971, 31 BVerfGE 275; Bundesverfassungsgericht [BVERFGE] [Federal Constitutional Court] 1978, 49 BVerfGE 382 (1978); Bundesverfassungsgericht [BVERFGE] [Federal Constitutional Court], Case No. 1 BvR 825/98, (June 29, 2000); Bundesverfassungsgericht [BVerfGE] [Federal Constitutional Court] Case No. 1 BvR 1585/13, (May 31, 2016); BVERFGE, Case no. 1 BvR 1213/16.

${ }^{132} 31$ BVerfGE 229 (para. 47).

${ }^{133} I d$. at para. 35 .

${ }^{134} I$ d. at para. 28, as translated by Donald P. Kommers \& Russell A. Miller, The Constitutional Jurisprudence of the Federal Republic of Germany 247-48 (2012).

${ }^{135} \mathrm{Id}$.

${ }^{136} I d$. at para. 34 . 
of Human Rights was left unanswered. The Court reasoned that although legislation never recognized authors' rights to include such uses, the argument against them is very weak. ${ }^{137}$ After all, other parties - such as publishers and printers - also make profit from distributing the educational materials, and potential licensing is unlikely to be excessively expensive. Therefore, in the Court's view, the legislator exceeded the boundaries which-based on Article 14(2) GGit must respect when it determines the content of the property authorizations. ${ }^{138}$ The Court held that lack of exclusive rights is already a gesture towards public interest, and there is no clear reason why the same should apply to the possibility of financial benefit from the use of authors' works based on compensation. ${ }^{139}$

This decision, which can be easily described as "putting right's into one's possession," was somewhat toned down by the next two cases, Bibliotheksgroschen and BearbeiterUrheberrechte, ${ }^{140}$ the first of which was handed down by the same court on the same day, and the second just a day after. In Bearbeiter-Urheberrechte, the Court had to decide about constitutionality of a legislative change that transformed the rights of performing artists into a neighboring right and, while doing so, also collaterally shortened or even ended the rights of some of the right holders. ${ }^{141}$ This was due to rules that applied the new criteria of duration and its calculation not only to new performances, but also those that predated the amendment.

The Court held that IP rights are not immune to legislative change. ${ }^{142}$ Article 14 GG, in its view, does not mean "inviolability of a legal position for all times." ${ }^{143}$ Not every change in the content of the legal position is automatically inadmissible. The legislator is also empowered to interfere in already existing rights and to give them new content. More explicitly, the Court said:

The property guarantee and the individual property shall not constitute an unsurmountable limit for the legislative powers when the reforms prove to be necessary. During the reform, the legislator is not placed before alternatives to either keep subjective rights based on the previous law, or to expropriate them under the conditions of Article 14(3) GG; it can also redesign the individual legal positions without violating the property guarantee. ${ }^{144}$

Because in this case, the legislator enacted largely the same rules with reference to the need for legal certainty, the Court engaged in a debate about its relevance. While the Court accepted that this principle is important and may justify interference with rights in case of a reform, ${ }^{145}$ it remained very critical of the fact that the same argument is used as the main reason for uncompensated deprivations of property. ${ }^{146}$ For these reasons, the Court invalidated the provision as long as it applied to pre-existing protected objects.

These cases show that while the German Constitutional Court is willing to give the legislator very broad room to maneuver its legislative (re)design, it is also ready to moderate it if needed. Although the Schulbuchprivileg case does not emphasize the essence of rights, the latest case-law, in particular Metall auf Metall, ${ }^{147}$ reformulates its findings in this light ${ }^{148}$ while also extending the principles to investment protection of phonogram producers. At the same time, following the

\footnotetext{
${ }^{137} I d$. at para. 47.

${ }^{138} \mathrm{Id}$. at para. 48.

${ }^{139} \mathrm{Id}$. at paras. $48-49$.

${ }^{140} 31$ BVerfGE 248; 31 BVerfGE 275.

${ }^{141} 31$ BVerfGE 275 (para. 25).

${ }^{142} I d$. at para. 28.

${ }^{143} \mathrm{Id}$.

${ }^{144} I d$. (translated).

${ }^{145} \mathrm{Id}$. at para. 46.

${ }^{146} \mathrm{Id}$. at paras. $51-52$.

${ }^{147}$ BVERFGE, Case No. 1 BvR 1585/13.

${ }^{148} I d$. at para. 72.
} 
Bearbeiter-Urheberrechte decision, legislative changes and reforms are broadly possible-including shortening, transformation, and deprivation-but subject to much higher standards than references to legal certainty. In particular, it appears that compensation is one of the key ingredients for more far-reaching changes. As a result, the German approach recognizes inviolable core rights, as evidenced by the Schulbuchprivileg and Kirchenmusik cases, ${ }^{149}$ and means that the legislator is broadly allowed to shape the intellectual property rights-such as by designing their applicability, scope, and duration. Nevertheless, it must still comply with a core obligation to provide some form of protection. ${ }^{150}$ It may not reduce the rights to zero entirely. ${ }^{151}$ The social purpose of rights is a source of legitimacy as well as limitation, both of which the German legislator must observe.

\section{Slovakia}

Unlike the German and English constitutional systems, the Slovak Constitution is much more explicit in its accommodation of IP rights. Its basic constitutional text implements A1P1-style property protection ${ }^{152}$ and a Covenant-style obligation to protect creators. ${ }^{153}$ In its seminal Tank Man II decision, ${ }^{154}$ the Constitutional Court explained that the Constitution clearly formulates a strong bond between the protection of intellectual creations on the one hand, and freedom of scientific research, artistic freedom, and the right to cultural participation on the other.

According to the Constitutional Court, Article 43 of the Constitution binds the state to create certain material conditions for inventors and creations, with the goal to promote artistic freedom and scientific research. ${ }^{155}$ Article 43 thus embodies the constitutional core of protection of creators. This obligation, inspired by Article 15 of the ICESCR, can be materialized through intellectual property rights, but also by other means. ${ }^{156}$ Furthermore, according to the court, these economic rights, provided for the purpose of the progress of science and culture, subsequently fall under the constitutional protection of property. ${ }^{157}$ The only unavoidable obligation to protect stems from the creator's rights. ${ }^{158}$ Even these rights, with reference to German doctrine, do not guarantee the possibility of benefitting from any use of such creations. At the same time, the Court notes the possible application of the author's interest in protection of his or her human dignity, honor, reputation, and name according to other provisions of the Constitution.

The case-law thus constructs a two-tier system of protection that, on the one hand, clarifies a broad discretion of the legislator, together with willingness to protect its choices, but on the other hand makes them subject to a specific purpose behind IP legislation. The ultimate purpose echoes the Covenant's demands to create material conditions for inventors and creators in order to promote artistic freedom and scientific research by safeguarding a minimum level of material conditions.

\footnotetext{
${ }^{149} 48$ BVerfGE 382 (expressing the court's objection to a non-remunerated exception in the copyright law).

${ }^{150}$ Rolf Schwartmann \& Christian-Henner Hentsch, Die verfassungsrechtlichen Grenzen der Urheberrechtsdebatte [The Constitutional Limits of the Copyright Debate], 2012 ZUM 759 (2012).

${ }^{151}$ BVERFGE, Case No. 1 BvR $1585 / 13$ at para. 74.

${ }^{152}$ See Ústava Slovenskej Republiky [CONStitution] Oct. 1, 1992, art. 20 [Slovk.].

${ }^{153} I d$. art. 43.

${ }^{154}$ See Case No. II. ÚS 647/2014-22 (2015); for a translation, see “Tank Man II”, INT'L Rev. INTELL. Prop. \& COMP. L. 729 (2015).

${ }^{155}$ Case No. II. ÚS 647/2014-22, at para 43.

${ }^{156} I d$. ("It is up to the state to decide how it will materialize this obligation. Copyright law is just one of the possible means. In any case, any provided protection is not an aim in itself, but only a means to achieve the societal goal of progress of science and art.").

${ }^{157}$ Case No. II. ÚS $647 / 2014-22$, at para 45 .

${ }^{158}$ Case No. II. ÚS 647/2014-22, at para 45.
} 


\section{Interim Summary}

Our brief analysis of the German, Slovak, and UK approach shows that constitutional traditions differ significantly in how they approach the question of the potential "essence" of intellectual property rights and its function. The UK jurisprudence equates its mechanisms with the Convention and the EU Charter, which, according to the reading of its domestic courts, provides no inviolable core rights at this point. German and Slovak constitutional jurisprudence do recognize inviolable core rights, but the obligations slightly differ. While the German obligation seems more far-reaching, as evidenced by case-law on the matter, the Slovak obligation seems relatively modest. They both equally emphasize the social function of IP rights and broad maneuvering space of the legislator and its ability to reform. Nevertheless, the Slovak approach, unlike the German one, seems to tie such inviolable core rights with individual creators - and potentially their dignity — while the German approach applies to a broader set of entities.

\section{International Obligations as Constitutional Traditions: Creator's Rights}

Common constitutional traditions constitute an integral part of the general principles of the law. ${ }^{159}$ While national constitutions are one of their sources, commonly shared international obligations might constitute another source of such traditions. After all, the Court enjoys discretion when formulating what exactly constitutes these constitutional traditions. ${ }^{160}$ Long before today's Article 6(3) of the TEU was adopted, the CJEU used this concept as a way to incorporate human rights considerations in its judicial review. As the Court explained in its seminal 1979 Hauer decision, their incorporation was necessary in order to assure that the norms of Union law "only be judged in the light of Community law itself." ${ }^{\prime 61}$ To safeguard unity and cohesion of the community, the Court "draws inspiration from constitutional traditions common to the Member States,"162 including "international treaties for the protection of human rights on which the Member States have collaborated or of which they are signatories." ${ }^{63}$ In Hauer, this way, the Court relied on the ECHR's safeguards included in A1P1. ${ }^{164}$

In the context of intellectual property, it is important to keep in mind the International Covenant on Economic, Social and Cultural Rights (ICESCR), which, in its Article 15(1)(c), includes an obligation to provide so called "creator's rights." The Member States "recognize the right of everyone ... to benefit from the protection of the moral and material interests resulting from any scientific, literary or artistic production of which he is the author." 165 The ICESCR is binding upon all Member States of the European Union, and some of them-such as Slovakiaeven directly implemented it in their constitutions. Its sibling, the International Covenant on Civil and Political Rights (ICCPR) is already widely recognized by the CJEU as an important source of Union law, despite the fact that the EU has never acceded to it. ${ }^{166}$

The ICESCR itself remains widely cited in the Advocate General's opinions as an equally important source of law. ${ }^{167}$ Recently, in Renckoff, Advocate General Campos Sánchez-Bordona even referenced it explicitly in a copyright dispute, although in the context of the right to

\footnotetext{
${ }^{159}$ Hauer, Case $44 / 79$ at para. 15.

${ }^{160}$ The CJEU has discretion in formulating the content of these traditions. See Céline Romainville, Defining the Right to Participate in Cultural Life as a Human Right, 33(4) NeTH. Q. Hum. RTs. 405, 416 (2015).

${ }^{161}$ Hauer, Case $44 / 79$ at para. 15.

${ }^{162} \mathrm{Id}$.

${ }^{163} \mathrm{Id}$.

${ }^{164} I d$. at para. 17.

${ }^{165}$ ICESCR, supra note 1 , at art. 15(1)(c).

${ }^{166}$ ECJ, Case C-540/03, Parliament v. Council, ECLI:EU:C:2006:429, Judgment of June 27, 2006, para. 37; ECJ, Case C-244/ 06, Dynamic Medien, ECLI:EU:C:2008:85, Judgment of Feb. 14, 2008, para. 39.

${ }^{167}$ See, e.g., Opinion of Advocate General Wathelet at para. 102, Case C-266/16, Western Sahara Campaign UK (Jan. 10, 2018), http://curia.europa.eu/juris/liste.jsf?num=C-244/06; ECJ, Case C-5/12, Betriu Montull, C-5/12, ECLI:EU:C:2013:571, Judgment of Sept. 19, 2013, para. 3.
} 
education. ${ }^{168}$ Moreover, as pointed out in the introduction, the language of Article 15 of the ICESCR originates from the Universal Declaration of Human Rights, a non-binding legal instrument that was subsequently accepted as part of customary international law. ${ }^{169}$

Based on the above, it is arguable that the creator's rights enshrined in Article 15 of the ICESCR actually constitute part of the Union law. This is potentially very significant because if the EU Charter had to identify any inviolable core of intellectual property rights under Article 17(2) of the EU Charter-in the sense of choices that cannot be undone by the legislator-creator's rights offer themselves as an obvious candidate. Nonetheless, Article 15 can at most stay at the level of inspiration.

Unlike the protection of purely economic interests enshrined in Article 17(2) of the EU Charter, the Article 15 ICESCR standard is grounded in the human dignity of individuals. It thus has a strong link to Article 1 of the EU Charter. According to Helfer, Article 15 obligations "encompass modest economic exploitation and personality guarantees that, taken together, are more circumscribed than those imposed by intellectual property treaties." 170 If we revisit the case-law of the CJEU, it is apparent that "the protection of the moral and economic rights" is already recognized as specific subject matter, or substance, of those rights. ${ }^{171}$ Nonetheless, again, Article 17(2) of the EU Charter only protects the economic side of interests.

In addition, General Comment No. 17 of the Committee on Economic, Social and Cultural Rights stresses that the scope of the positive obligation underlying Article 15(1) "need not necessarily reflect the level and means of protection found in present copyright, patent and other intellectual property regimes, as long as the protection available is suited to secure for authors the moral and material interests resulting from their productions." ${ }^{172}$ In other words, this could mean that Article 17(2) and its core could, in some circumstances, actually turn itself against the legislative design of intellectual property rights, with a view to emphasizing the interests of creators among the entire set of right holders.

Last but not least, incorporating Article 15 considerations into Article 17(2) would mean that when it comes to essence, not all right holders are equal. This is because Article 15 does not protect legal entities, but only creators themselves. According to the General Comment, only the "author," namely the creator - whether man or woman, individual or group of individuals - of scientific, literary, or artistic productions-such as, inter alia, writers and artists, enjoy the protection. ${ }^{173}$ Pure investors would thus benefit from no guaranteed core rights, and be protected only upon legislator's decisions, which in itself is not necessarily a bad outcome.

To account for differences in structure and goals, if the core ever were to be recognized, even only as an analytical tool within the proportionality exercise, the Court could try to conceptualize it in light of Article 15 of the Covenant. After all, Article 15 should find some reflection within the EU Charter anyway. To be sure, this does not mean mirroring its content within Article 17(2), but only internalizing the economic limb of its imperative that individuals-not corporations - should have a modest claim to reap economic fruits of their personal creations. Such an imperative can

\footnotetext{
${ }^{168}$ ECJ, Case C-161/17, Renckhoff, ECLI:EU:C:2018:279, Judgment of Aug. 7, 2008, para. 115, fn. 80.

${ }^{169}$ Caterina Sganga, Right to Culture and Copyright: Participation and Access, in ResEARCH HaNDBOOK ON HUMAN RigHTS AND INTEllectual Property, supra note 4, at 560, 572.

${ }^{170}$ Laurence R. Helfer \& Graeme Austin, Human Rights and Intellectual Property 513 (2011).

${ }^{171}$ Phil Collins Case, Case C-92/92 at para. 20.

${ }^{172}$ U.N., Econ. \& Soc. Council, Comm. on Econ., Soc. \& Cultural Rights, General Comment No. 17, The Right of Everyone to Benefit from the Protection of the Moral and Material Interests Resulting from any Scientific, Literary or Artistic Production of Which He or She is the Author (Article 15, Paragraph 1 (c), of the Covenant), U.N. Doc. E/C.12/GC/17 (2005).

${ }^{173} I d$. at para. 7.

The Committee considers that only the "author", namely the creator, whether man or woman, individual or group of individuals, of scientific, literary or artistic productions, such as, inter alia, writers and artists, can be the beneficiary of the protection of article 15, paragraph 1 (c) .... Under the existing international treaty protection regimes, legal entities are included among the holders of intellectual property rights. However, as noted above, their entitlements, because of their different nature, are not protected at the level of human rights.
} 
also be inferred from reading Article 17(2)'s essence in light of Article 1 of the EU Charter, which is limited to humans and their dignity.

\section{E. Conclusions}

This Article has shown that the Court of Justice of the European Union does not subscribe to the absolute theory of essence of rights in the area of intellectual property. The essence is not applied systematically, and usually only supports the argumentation. The closest doctrine to essence, at this point, is the specific subject matter doctrine known from market freedoms case-law. Nevertheless, this essence is not conceptualized as an inviolable core that the legislator cannot take away. It is only viewed as a tool to identify the core features of the design of various intellectual property rights and their substance, which are then less easily weighted against conflicting interests. The essence of legislative design is not the same as the essence of a fundamental right. Even if the Court ever develops the latter notion of essence in intellectual property law, it should attempt to construe it in light of other international obligations - in particular the International Covenant on Economic, Social and Cultural Rights. Borrowing from this external standard of creator's rights might help bridge the differences between diverging constitutional traditions in the Member States.

Cite this Article: Husovec M (2019). The Essence of Intellectual Property Rights Under Article 17(2) of the EU Charter. 